\title{
Paternal versus maternal transmission of a stimulatory G-protein $\alpha$ subunit knockout produces opposite effects on energy metabolism
}

\author{
Shuhua Yu, ${ }^{1}$ Oksana Gavrilova, ${ }^{2}$ Hui Chen, ${ }^{3}$ Randy Lee, ${ }^{1}$ Jie Liu, ${ }^{1}$ Karel Pacak, ${ }^{4}$ \\ A.F. Parlow, ${ }^{5}$ Michael J. Quon, ${ }^{3}$ Marc L. Reitman, ${ }^{2}$ and Lee S. Weinstein ${ }^{1}$ \\ ${ }^{1}$ Metabolic Diseases Branch, National Institute of Diabetes, Digestive, and Kidney Diseases, \\ ${ }^{2}$ Diabetes Branch, National Institute of Diabetes, Digestive, and Kidney Diseases, \\ ${ }^{3}$ Hypertension-Endocrine Branch, National Heart, Lung, and Blood Institute, and \\ ${ }^{4}$ Clinical Neurocardiology Section, National Institute of Neurological Diseases and Stroke, National Institutes of Health, \\ Bethesda, Maryland 20892, USA \\ ${ }^{5}$ National Hormone and Pituitary Program, Harbor-UCLA Medical Center, Torrance, California 90509, USA \\ Address correspondence to: Lee S. Weinstein, Metabolic Diseases Branch, National Institute of Diabetes, Digestive, and \\ Kidney Diseases, National Institutes of Health, Building 10 Room 8C101, Bethesda, Maryland 20892-1752, USA. \\ Phone: (301) 402-2923; Fax: (301) 402-0374; E-mail: leew@amb.niddk.nih.gov.
}

Received for publication September 15, 1999, and accepted in revised form January 18, 2000.

\begin{abstract}
Heterozygous disruption of $G n a s$, the gene encoding the stimulatory G-protein $\alpha$ subunit $\left(\mathrm{G}_{\mathrm{s}} \alpha\right)$, leads to distinct phenotypes depending on whether the maternal $(\mathrm{m}-/+)$ or paternal $(+/ \mathrm{p}-)$ allele is disrupted. $\mathrm{G}_{\mathrm{s}} \alpha$ is imprinted, with the maternal allele preferentially expressed in adipose tissue. Hence, expression is decreased in $\mathrm{m}-/+$ mice but normal in $+/ \mathrm{p}-$ mice. $\mathrm{M}-/+$ mice become obese, with increased lipid per cell in white and brown adipose tissue, whereas $+/ \mathrm{p}-$ mice are thin, with decreased lipid in adipose tissue. These effects are not due to abnormalities in thyroid hormone status, food intake, or leptin secretion. $+/ \mathrm{p}$ - mice are hypermetabolic at both ambient temperature $\left(21^{\circ} \mathrm{C}\right)$ and thermoneutrality $\left(30^{\circ} \mathrm{C}\right)$. In contrast, $\mathrm{m}-/+$ mice are hypometabolic at ambient temperature and eumetabolic at thermoneutrality $\mathrm{M}-/+$ and wild-type mice have similar dose-response curves for metabolic response to a $\beta_{3}$-adrenergic agonist, CL316243, indicating normal sensitivity of adipose tissue to sympathetic stimulation. Measurement of urinary catecholamines suggests that $+/ \mathrm{p}-$ and $\mathrm{m}-/+$ mice have increased and decreased activation of the sympathetic nervous system, respectively. This is to our knowledge the first animal model in which a single genetic defect leads to opposite effects on energy metabolism depending on parental inheritance. This probably results from deficiency of maternal- and paternal-specific Gnas gene products, respectively.
\end{abstract}

J. Clin. Invest. 105:615-623 (2000).

\section{Introduction}

Heterotrimeric $\mathrm{G}$ proteins transduce extracellular signals from 7 transmembrane receptors to intracellular effectors. Each $\mathrm{G}$ protein is composed of distinct $\alpha, \beta$, and $\gamma$ subunits (1). The $\alpha$ subunit binds guanine nucleotide and interacts with specific receptors and effectors, such as adenylyl cyclase, phospholipase $\mathrm{C}$, and ion channels. $\mathrm{G}_{\mathrm{s}} \alpha$ is an $\alpha$ subunit that is ubiquitously expressed and transmits a stimulatory signal from hormone-bound receptors to adenylyl cyclase, leading to cAMP generation.

Heterozygous inactivating mutations within human GNAS1 (the gene encoding $\mathrm{G}_{\mathrm{s}} \alpha$ located at 20q13.2-13.3; ref. 2) lead to Albright hereditary osteodystrophy (AHO), a dominantly inherited disorder characterized by obesity, short stature, and skeletal defects (3). Maternal transmission of GNAS1 mutations leads to AHO plus multihormone resistance (termed pseudohypoparathyroidism type Ia [PHP Ia]), while paternal transmission leads to AHO alone (termed pseudopseudohypoparathyroidism [PPHP]) (4). Imprinting is an epigenetic phenomenon characterized by parental allele-specific differences in gene expression (5-7). In mice, $G_{s} \alpha$ is expressed primarily from the maternal allele in some tissues, such as renal proximal tubules and adipose tissue but is not imprinted in other tissues (8). This probably explains why only maternal inheritance of GNAS1 mutations leads to hormone resistance in patients with $\mathrm{AHO}$, although $\mathrm{G}_{\mathrm{s}} \alpha$ has not been definitively proved to be imprinted in humans (9).

In addition to $\mathrm{G}_{\mathrm{s}} \alpha$, GNAS1 and the murine homolog Gnas encode 2 additional gene products via use of alternative promoters and upstream exons that splice to the common second exon. XL $\alpha$ s, an isoform of $\mathrm{G}_{\mathrm{s}} \alpha$ localized to Golgi, is transcribed exclusively from the paternal allele, whereas NESP55, a chromogranin-like neurosecretory protein, is transcribed exclusively from the maternal allele (10-12). Both are expressed primarily in neuroendocrine tissues, and their biologic functions have not been elucidated (13-17).

We generated mice with an insertional disruption of Gnas exon 2 (GsKO), an exon common to all known Gnas transcripts. Homozygotes (-/-) die during early postimplantation development, whereas heterozygotes with disruption of the paternal $\left(+/ \mathrm{p}^{-}\right)$or maternal $(\mathrm{m}-/+)$ allele have distinct phenotypic manifestations 
(8), many of which are similar to mice with maternal and paternal uniparental disomies of the distal chromosome 2 region to which Gnas maps, respectively (18, 19). (Uniparental disomy is the inheritance of both copies of a chromosome or subchromosomal region from a single parent). The $+/ \mathrm{p}-$ mice are smaller than normal at birth, fail to suckle, and most die within several hours probably as a result of severe hypoglycemia. In contrast, $\mathrm{m}-/+$ are larger than normal at birth and most die 1-3 weeks after birth. These distinct phenotypes are presumably due to the fact that Gnas is an imprinted gene. An interesting difference between the $\mathrm{m}-/+$ and $+/ \mathrm{p}-$ mice that survive past weaning $(\sim 20-25 \%$ of each group) is their opposite changes in fat mass, with increased and decreased fat accumulation in adipose tissue of $\mathrm{m}-/+$ and $+/ \mathrm{p}$ - mice, respectively. In this report, we characterize these phenotypes in detail and show that these changes are associated with decreased and increased energy metabolism in $\mathrm{m}-/+$ and $+/ \mathrm{p}-$ mice, respectively.

\section{Methods}

Mice. Mice with insertion of a neomycin resistance cassette into exon 2 of Gnas were previously created by targeted mutagenesis (8). Female heterozygotes were mated to wild-type CD-1 males (Charles River Laboratories, Wilmington, Massachusetts, USA), and male heterozygotes were mated to wild-type CD-1 females to generate $\mathrm{m}-/+$ and $+/ \mathrm{p}$ - mice, respectively. Animals were maintained on a 12-hour light/dark cycle (0600/1800 hours) and standard pellet diet (NIH-07, 5\% fat by weight; Zeigler Brothers Inc., Gardners, Pennsylvania, USA) and studied at $21-25^{\circ} \mathrm{C}$ unless noted otherwise. In all studies, $\mathrm{m}-/+$ and $+/ \mathrm{p}$ - mice were studied along with sex-matched wild-type littermates (designated $\mathrm{m}^{+} /+$and $+/ \mathrm{p}^{+}$, respectively), and statistical significance was determined using an unpaired $t$ test.

Blood and tissue analysis. Serum triglycerides and cholesterol were determined by Ani-Lytics, Inc. (Gaithersburg, Maryland, USA). Serum thyrotropin (TSH) was measured by double antibody RIA (National Hormone and Pituitary Program of the National Institute of Diabetes, Digestive, and Kidney Diseases, National Institutes of Health [NIH], Torrance, California, USA). Thyroid hormones were measured by RIA (NIH Clinical Pathology Department). Leptin was measured by RIA using a commercial kit (Linco Research, St. Charles, Missouri, USA). For histological examinations, tissues were fixed in $10 \%$ neutral buffered formalin (4\% formaldehyde; Sigma Chemical Co., St. Louis, Missouri, USA), paraffin-embedded, and sections were stained with hematoxylin and eosin.

Food intake studies. Six-week-old male mice were individually caged, and rodent chow was weighed and placed in the bottom of each cage without bedding. Remaining food was weighed 3 and 7 days later. Within each group, there was no difference in the rate of food intake between days 1-3, 3-7, or 1-7.
Indirect calorimetry and in vivo responsiveness to $\beta_{3}$-adrenergic stimulation. Oxygen consumption was measured using a 4-chamber Oxymax system (Columbus Instruments, Columbus, Ohio, USA; $2.5 \mathrm{~L}$ chambers with wire mesh floors, using $1 \mathrm{~L} / \mathrm{min}$ flow rate, 75 -second purge, and 60-second measure), with 1 mouse per chamber. Motor activity (total and ambulating) was determined by infrared beam interruption (Opto-Varimex mini; Columbus Instruments). Resting oxygen consumption was calculated as the average of the points with less than 6 ambulating beam breaks per minute.

The effect of the $\beta_{3}$-specific adrenergic agonist CL316243 (20) was measured as follows, with each mouse serving as its own control. At approximately 0900 hours, mice were placed into the calorimetry chambers, which were prewarmed to $30^{\circ} \mathrm{C}$, and baseline data were collected. Three hours later, CL316243 was injected intraperitoneally at the indicated dose (from a $1 \mathrm{mg} / \mathrm{mL}$ stock in saline), and, after a 1 hour delay, data were collected for 2 hours. Food and water were available at all times.

To measure the response of serum glycerol and FFAs to $\beta_{3}$-adrenergic stimulation, a maximal dose of CL316243 $(1,000 \mu \mathrm{g} / \mathrm{kg}$ intraperitoneally) was administered at 1400 hours to 8 -week-old male mice that were fasted for 6 hours. Blood was collected from their tail vein before and after injection, and serum glycerol (no. 339-11; Sigma Chemical Co.) and FFA (no. 1383175; Boehringer Mannheim) were measured.

Measurement of urinary catecholamines and metabolites. Mice were placed individually in mouse metabolic cages (Nalgene; Nalge Nunc Internationsl, Rochester, New York, USA) for 3 days of acclimatization, and then urine was collected over the next 3 days. Urine $\mathrm{pH}$ was maintained $\leq 3$ with $\mathrm{HCl}$; urine volume was measured; and aliquots were frozen at $-70^{\circ} \mathrm{C}$. Food and water were provided ad libitum throughout the collection. Urine catecholamines and their metabolites were measured by HPLC (21). Urine creatinine concentration was measured using the Cobas Mira analyzer (Roche Diagnostic Systems, Branchburg, New Jersey, USA).

Northern analysis. Total RNA was isolated from tissues by the TRIZol method (GIBCO BRL), Rockville, Maryland, USA). Rat uncoupling protein 1 (UCP1) (22), mouse UCP3 (23), and mouse $\mathrm{G}_{\mathrm{s}} \alpha$ (coding region nucleotides 1-125; ref. 24) probes were labeled with ${ }^{32} \mathrm{P}$ by random priming. Northern analysis was performed as described previously (25), using $15 \mu \mathrm{g}$ total RNA per lane except that the hybridization temperature was $45^{\circ} \mathrm{C}$ for the UCP1 probe and $42^{\circ} \mathrm{C}$ for the UCP3 probe and the final wash temperature was $55^{\circ} \mathrm{C}$ for the $\mathrm{G}_{\mathrm{s}} \alpha$ probe. To normalize for loading differences, $28 \mathrm{~S}$ ribosomal RNA was stained with ethidium bromide and quantified using Gel Expert software (NucleoTech Corp., San Mateo, California, USA).

Membrane preparation and immunoblot analysis. To prepare total membranes from brown adipose tissue (BAT), the tissue was homogenized in ice-cold membrane buffer $(0.25 \mathrm{M}$ sucrose, $10 \mathrm{mM}$ Tris, $1 \mathrm{mM}$ EDTA, $1 \mathrm{mM} \mathrm{MgCl} 2$ [pH 7.4], containing protease 


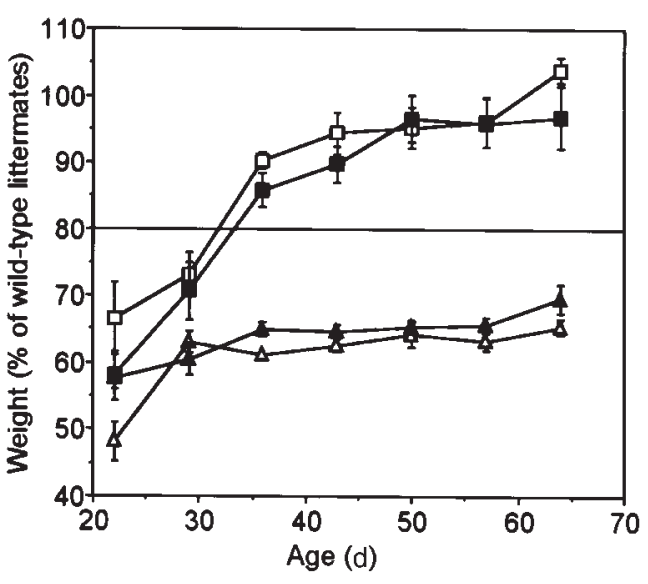

Figure 1

Weight curves of $\mathrm{m}-/+$ and $+/ \mathrm{p}-$ mice. To control for genetic background variability, the weight of each mutant mouse is expressed as a percent of the weight of wild-type littermates of the same age and sex. The data (male $\mathrm{m}-/+$, filled square; female $\mathrm{m}-/+$, open square; male $+/ \mathrm{p}^{-}$, filled triangle; female $+/ \mathrm{p}^{-}$, open triangle; $n=10-39$ per group) were binned using 1-week intervals and expressed as mean \pm SEM. Because mutant mice are short, a normal BMI corresponds to a weight of approximately $80 \%$ of wild-type littermates (see the text and Table 3). By 60 days, all m-/+ mice weighed greater than $80 \%$ of wild-type, whereas all $+/ p$ - mice weighed less than $80 \%$ of wild-type.

inhibitor [Complete capsules; Boehringer Mannheim]) with a Teflon pestle and centrifuged at $250 \mathrm{~g}$ for 10 minutes at $20^{\circ} \mathrm{C}$. The supernatant was recentrifuged at $436,000 \mathrm{~g}$ in a TLA100.3 rotor (Beckman Instruments Inc., Fullerton, California, USA) for 30 minutes at $4^{\circ} \mathrm{C}$, and the membrane pellet was resuspended in membrane buffer and stored at $-70^{\circ} \mathrm{C}$. Protein concentrations were determined using the BCA kit (Pierce Chemical Co., Rockford, Illinois, USA). Immunoblotting using a $\mathrm{G}_{\mathrm{s}} \alpha$-specific antibody was performed as described previously (8). To normalize for loading differences, relative amounts of protein in each sample was determined by Coomassie blue staining and quantification with Gel Expert software.

\section{Results}

Maternal versus paternal inheritance of $a G_{s} \alpha$ knockout allele leads to opposite effects on lipid metabolism. Within days after birth, $\mathrm{m}-/+$ and $+/ \mathrm{p}-$ mice can be distinguished by their body habitus. The $+/ \mathrm{p}^{-}$ mice are very thin, whereas $\mathrm{m}-/+$ mice tend toward obesity. At weaning ( $\sim 22$ days) both $\mathrm{m}-/+$ and $+/ \mathrm{p}-$ mice weighed less than their littermates (Figure 1), reflecting delayed development in both groups of mutant mice (8). Over the next 3 weeks, $\mathrm{m}-/+$ mice gained weight significantly faster than their wild-type littermates, while $+/ \mathrm{p}^{-}$mice remained

\section{Table 1} 0.065 versus wild-type littermates. underweight. Because body mass index (BMI) is inversely proportional to the square of the length, and the length of both $\mathrm{m}-/+$ and $+/ \mathrm{p}-$ mice averaged approximately $90 \%$ of wild-type (Table 1 ), a relative weight of approximately $80 \%$ (rather than 100\%) reflects a BMI equivalent to that of wild-type mice. By day 60 , all $+/ \mathrm{p}$ - mice still weighed less than $80 \%$ of their littermates, whereas $\mathrm{m}-/+$ mice weighed more than $80 \%$ (with many greater than 100\%) of their littermates. Males and females had similar relative weight curves for both groups. Serum triglycerides and cholesterol tended to be lower in $\mathrm{m}-/+$ mice and were significantly reduced in $+/ \mathrm{p}-$ mice (Table 2 ).

At birth, interscapular BAT had a similar gross and microscopic appearance in $\mathrm{m}-/+,+/ \mathrm{p}-$, and wild-type mice (data not shown). Over the next 2 days, $\mathrm{m}-/+$ and $+/ \mathrm{p}-$ mice showed drastic and opposite changes in BAT lipid accumulation. The interscapular BAT pads in $+/ \mathrm{p}$ - mice were smaller and more brown than those in wild-type mice, whereas in $\mathrm{m}-/+$, mice they were larger and lighter in color. Microscopically there was little lipid accumulation in $+/ \mathrm{p}$ - mice (Figure 2a, left panel), whereas in $\mathrm{m}-/+$ mice (Figure 2a, right panel), BAT cells had large lipid droplets, giving them the appearance of white adipose tissue (WAT). Likewise, histological examination of WAT revealed markedly decreased and increased lipid per cell in $+/ \mathrm{p}$ - and $\mathrm{m}-/+$ mice, respectively (Figure 2a). These opposite effects on BAT and WAT fat pad mass were maintained throughout the adult period (Table 1). Taken together, these data suggest that BAT is more active in $+/ \mathrm{p}-$ mice and less active in $\mathrm{m}-/+$ mice when compared with littermate controls.

Uncoupling proteins are mitochondrial proteins that uncouple substrate oxidation from the generation of ATP, leading to energy dissipation as heat $(26,27)$. UCP1 is expressed only in BAT and is positively regulated by sympathetic ( $\beta$-adrenergic) stimulation, which also increases metabolic activity (26-28). Typically, BAT histology correlates with UCP1 mRNA levels. Histologically, BAT in $+/ \mathrm{p}$ - mice appears more metabolically active, whereas BAT in $\mathrm{m}-/+$ mice appears less metabolically active. Consistent with this, UCP1 mRNA expression in BAT tended to be increased in $+/ \mathrm{p}-$ mice and decreased in $\mathrm{m}-/+$ mice (Figure $2 \mathrm{~b}$ ). Expression of the uncoupling protein $\mathrm{UCP} 3$ in $\mathrm{BAT}$ of $+/ \mathrm{p}-$ and $\mathrm{m}-/+$ mice was similar to that of wild-type (Figure $2 \mathrm{~b}$ ). Mus-

Length, BMI, and fat mass measurements of adult male mice ${ }^{A}$

\begin{tabular}{lcccc}
\hline & $+/ \mathrm{p}^{+}$ & $+/ \mathrm{p}^{-}$ & $\mathrm{m}+/+$ & $\mathrm{m}-/+$ \\
& $58.8 \pm 1.9(13)$ & $34.8 \pm 2.1(13)^{\mathrm{B}}$ & $55.2 \pm 2.6(14)$ & $56.2 \pm 2.5(14)$ \\
eight $(\mathrm{g})$ & $11.4 \pm 0.1(13)$ & $10.0 \pm 0.1(13)^{\mathrm{B}}$ & $11.3 \pm 0.1(14)$ & $10.6 \pm 0.1(14)^{\mathrm{B}}$ \\
ngth $(\mathrm{cm})^{\mathrm{C}}$ & $0.46 \pm 0.01(13)$ & $0.34 \pm 0.02(13)^{\mathrm{B}}$ & $0.43 \pm 0.02(14)$ & $0.50 \pm 0.02(14)^{\mathrm{B}}$ \\
MI $\left(\mathrm{g} / \mathrm{cm}^{2}\right)^{\mathrm{D}}$ & $1.54 \pm 0.17(11)$ & $0.74 \pm 0.16(11)^{\mathrm{B}}$ & $1.87 \pm 0.27(11)$ & $2.36 \pm 0.37(11)$ \\
Epididymal WAT weight $(\mathrm{g})$ & $190 \pm 45(10)$ & $76 \pm 15(10)^{\mathrm{B}}$ & $271 \pm 63(7)$ & $631 \pm 166(7)^{\mathrm{E}}$
\end{tabular}

AMeasurements of $+/ \mathrm{p}$ - and $\mathrm{m}-/+$ mice (4- to 8 -month old) and wild-type littermates $(+/ \mathrm{p}+$ and $\mathrm{m}+/+$, respectively) expressed as mean $\pm \operatorname{SEM}(n) .{ }^{\mathrm{B} P}<0.05$ versus wild-type littermates. ${ }^{C}$ Length measured from tip of nose to anus. ${ }^{D B M I}$ is total body weight $(\mathrm{g})$ divided by the square of the nasoanal length $(\mathrm{cm})$. ${ }^{E} P=$ 


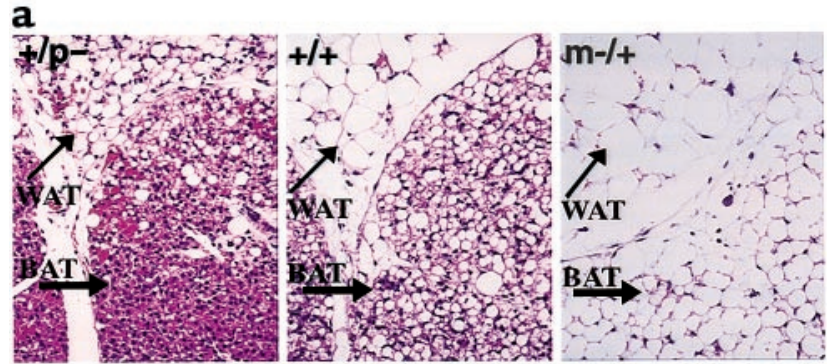

b

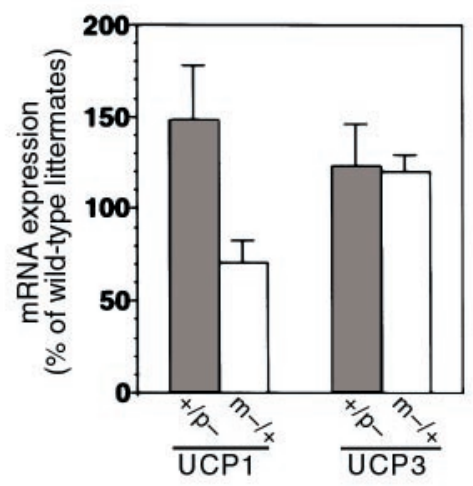

\section{Figure 2}

Fat accumulation and UCP expression in adipose tissue. (a) Histological sections of interscapular BAT and subcutaneous WAT after hematoxylin and eosin staining from 2-day-old mice. In m-/+ mice (right), there is markedly increased lipid accumulation in both BAT and WAT when compared with wild-type mice (center, +/+). In contrast, there is markedly reduced lipid accumulation in both BAT and WAT in $+/ p-$ mice (left). Original magnification, $\times 100$. (b) UCP1 (left) and UCP3 (right) mRNA levels in BAT from $+/ p$ - (filled bar) and $\mathrm{m}-/+$ (open bar) expressed as percent of wild-type littermates (UCP1, $n=5$ pairs of mice in each group, $\mathrm{m}-/+$ versus wild type, $P=$ 0.056 ; UCP3, $n=4$ pairs for $+/ \mathrm{p}-$ and 3 pairs for $\mathrm{m}-/+$ ).

cle UCP3 expression was also unaffected $(+/ \mathrm{p}-$ mice: $100 \pm 9 \%$ of wild-type, $n=5$ pairs; $\mathrm{m}-/+$ mice: $97 \pm 10 \%$ of wild-type, $n=5$ pairs).

Thyroid hormone is a major regulator of basal metabolic rate, and patients with PHP Ia who have mutations in the maternal allele of the human homolog GNAS1 are hypothyroid due to TSH resistance (3). However, there were no differences in serum TSH, triiodothyronine (T3), or thyroxine (T4) between $+/ \mathrm{p}^{-}$, $\mathrm{m}-/+$, and wild-type mice (Table 2 ). Therefore the differences in fat accumulation are not due to differences in activity of the thyroid axis. These results are consistent with the fact that there were no differences in UCP3 expression (see earlier discussion here), as UCP3 expression is known to be regulated by thyroid hormone (22).

Leptin is a circulating hormone released by adipose tissue that lowers food intake and stimulates metabolic activity (29). Serum leptin levels strongly correlate with body fat stores and with BMI (30). Because leptin expression is affected by $\beta$-adrenergic stimulation through $\mathrm{G}_{\mathrm{s}}$-coupled pathways (31), we measured serum leptin levels. In both male and female mice, serum leptin levels correlated with BMI (Figure 3 ) and gonadal fat pad weights (data not shown) in both mutant and wild- type animals. It is therefore unlikely that the differences in lipid metabolism observed in $+/ \mathrm{p}-$ and $\mathrm{m}-/+$ mice are due to abnormal regulation of leptin levels.

We have shown that $\mathrm{G}_{s} \alpha$ protein expression in WAT membranes is normal in $+/ \mathrm{p}-$ mice and reduced in $\mathrm{m}-/+$ mice, consistent with $\mathrm{G}_{\mathrm{s}} \alpha$ being paternally imprinted (silenced) in WAT (8). We also showed that $\mathrm{G}_{\mathrm{s}} \alpha$ mRNA levels in BAT are reduced only in $\mathrm{m}-/+$ mice, consistent with paternal imprinting of $G_{s} \alpha$ in BAT as well. We now measured $\mathrm{G}_{s} \alpha$ protein in BAT membranes by immunoblotting. $G_{s} \alpha$ protein levels were normal in $+/ \mathrm{p}$ - mice (101 $\pm 14 \%$ of wild-type; $n=$ 5 pairs) and reduced in $\mathrm{m}-/+$ mice $(40 \pm 7 \%$ of wildtype; $n=5$ pairs; $P=0.001$ versus wild-type). In contrast, $\mathrm{G}_{\mathrm{s}} \alpha$ is not imprinted in skeletal muscle, as $\mathrm{G}_{\mathrm{s}} \alpha$ mRNA was similarly reduced in $+/ \mathrm{p}-$ and $\mathrm{m}-/+$ mice $(+/ \mathrm{p}-$ mice: $45 \pm 6 \%$ of wild-type; $\mathrm{m}-/+$ mice $55 \pm 6 \%$ of wildtype; $n=5$ pairs for each).

Food intake and energy metabolism studies. Differences in fat accumulation reflect differences in either energy (food) intake, energy expenditure, or both. Food intake was normal in both $\mathrm{m}-/+$ and $+/ \mathrm{p}-$ mice (Figure 4a) and therefore cannot account for the opposite effects on adiposity. In fact, there is a trend toward increased food intake in $+/ \mathrm{p}$ - mice and decreased food intake in $\mathrm{m}-/+$ mice. We next examined resting metabolic rate (RMR) by indirect calorimetry. Initially, we examined the RMR of older mice over a 24-hour period at normal ambient temperature $\left(21^{\circ} \mathrm{C}\right)$. RMR in $+/ \mathrm{p}$ - mice was $23 \%$ greater than, and RMR in $\mathrm{m}-/+$ mice was 28\% less than, that of controls (Figure 4b). In both cases, the differences were significant. These data suggest that $+/ \mathrm{p}-$ mice are hypermetabolic and that $\mathrm{m}-/+$ mice are hypometabolic. Simultaneously measured total and ambulating activities were significantly increased in $+/ \mathrm{p}$ - mice (Figure $4 \mathrm{c}$ ). In contrast, locomotor activity was decreased in $\mathrm{m}-/+$ mice (Figure 4c; significant only for ambulating activity). These opposite changes in activity should lead to even greater changes in total energy expenditure in $+/ \mathrm{p}-$ and $\mathrm{m}-/+$ mice.

We next examined metabolic rate before and after maximal $\beta_{3}$-adrenergic stimulation (CL316243) at thermoneutrality $\left(30^{\circ} \mathrm{C}\right.$; refs. 32 and 33$)$. The RMR at thermoneutrality reflects the metabolic activity of lean body mass, with minimal sympathetic stimulation of adipose tissue (34). Metabolic activity in response to CL316243 presumably represents the maximal metabolic response of adipose tissue, as mice with no adipose tissue do not increase their metabolic rate in response to CL316243 (O. Gavrilova, unpublished observations). The $+/ \mathrm{p}^{-}$, $\mathrm{m}-/+$, and wild-type mice had similar metabolic rates after administration of CL316243 (Figure 4d), indicating that all are capable of achieving a similar maximal metabolic rate. However, at $30^{\circ} \mathrm{C},+/ \mathrm{p}-$ mice had a higher RMR than did either $\mathrm{m}-/+$ or wild-type mice, both in terms of absolute rate of oxygen consumption and in terms of percent of maximal stimulation $\left(71 \%\right.$ for $+/ \mathrm{p}^{-}$ mice versus $55 \%$ for wild-type littermates; $P<0.01$ ). The 
Table 2

Serum triglyceride, cholesterol, TSH, and thyroid hormone measurements ${ }^{\mathrm{A}}$

\begin{tabular}{lcccc}
\hline & $+/ \mathrm{p}^{+}$ & $+/ \mathrm{p}^{-}$ & $\mathrm{m}+/+$ & $\mathrm{m}-/+$ \\
& $197 \pm 24(7)$ & $117 \pm 17(11)^{\mathrm{B}}$ & $169 \pm 18(7)$ & $135 \pm 8(7)$ \\
Triglyceride $(\mathrm{mg} / \mathrm{dL})$ & $201 \pm 22(7)$ & $126 \pm 8(11)^{\mathrm{B}}$ & $183 \pm 17(7)$ & $152 \pm 17(7)$ \\
Cholesterol $(\mathrm{mg} / \mathrm{dL})$ & $2011 \pm 20(6)$ & $368 \pm 37(6)$ & $313 \pm 18(5)$ & $321 \pm 7(5)$ \\
$\mathrm{TSH}(\mathrm{ng} / \mathrm{mL})$ & $911.3 \pm 5.3(5)$ & $92.2 \pm 4.8(5)$ & $95.2 \pm 3.3(4)$ & $90.8 \pm 0.8(4)$ \\
$\mathrm{T} 3(\mathrm{ng} / \mathrm{dL})$ & $6.72 \pm 0.37(5)$ & $7.43 \pm 0.66(5)$ & $7.67 \pm 0.32(4)$ & $5.81 \pm 1.16(4)^{\mathrm{C}}$ \\
$\mathrm{T} 4(\mu \mathrm{g} / \mathrm{dL})$ & &
\end{tabular}

${ }^{A}$ Random morning measurements in 3- to 4-month-old male +/p-, m-/+, and wild-type mice expressed as mean \pm SEM $(n)$. T3 and T4 were measured in 7-month-old male mice. ${ }^{\mathrm{B}} P<0.05$ versus wild-type littermates. CIncludes 1 outlying value of 2.40 in a mouse in which the simultaneous T3 was 90.1.

glucose decreasing (data not shown) Similar results for serum glycerol, FFA, insulin, and glucose were obtained in the fed state (data not shown).

Urinary catecholamines and their metabolites. Because $G_{s} \alpha$ expression in adipose tissue of $+/ p$ - mice is normal and the decrease in $G_{s} \alpha$ expression in adipose tissue of $\mathrm{m}-/+$ mice is apparently insufficient to produce resistance to sympathetic stimulation, we next tried to determine whether the opposite effects in energy metabolism between $+/ \mathrm{p}-$ and

+/p- mice are both hypermetabolic and more active, and this plausibly explains why these mice have markedly decreased body fat.

Although older $\mathrm{m}-/+$ mice were hypometabolic at $21^{\circ} \mathrm{C}$, the RMRs of younger $\mathrm{m}-/+$ and wild-type mice are similar at $30^{\circ} \mathrm{C}$ (Figure $4, \mathrm{~d}$ and e; $30^{\circ} \mathrm{C}$; no CL316243). The low metabolic rate at $21^{\circ} \mathrm{C}$ was confirmed in a group of younger $\mathrm{m}+/-$ mice (Figure $4 \mathrm{e}$; $21^{\circ} \mathrm{C}$; no CL316243). When compared with the RMR at $30^{\circ} \mathrm{C}$, lowering the environmental temperature caused a significant increase in RMRs in both $\mathrm{m}-/+$ and wild-type mice as a result of increased sympathetic stimulation, but the increase in $\mathrm{m}-/+$ mice was not as great as that in wild-type mice. Therefore, relative to wild-type mice, $\mathrm{m}-/+$ mice are both hypometabolic and less active, and this is most likely the reason that these mice have increased fat stores.

$\mathrm{G}_{\mathrm{s}} \alpha$ is required for sympathetic stimulation of lipolysis in WAT and thermogenesis in BAT. Therefore decreased $G_{s} \alpha$ expression in adipose tissue might lead to decreased $\beta$-adrenergic sensitivity and decreased $\mathrm{RMR}$ in $\mathrm{m}-/+$ mice. To examine directly the responsiveness of adipose tissue to $\beta$-adrenergic stimulation in vivo, oxygen consumption was measured after administration of various doses of CL316243 at $30^{\circ} \mathrm{C}$ (Figure 4e). The dose-response curves for $\mathrm{m}-/+$ and wild-type littermates were virtually identical, even at doses that produced metabolic rates similar to those observed at $21^{\circ} \mathrm{C}$ in the absence of $\beta_{3}$ agonist (Figure $4 \mathrm{e} ; 21^{\circ} \mathrm{C}$; no CL316243). These results indicate that adipose tissue in $\mathrm{m}-/+$ mice is normally responsive to $\beta$-adrenergic stimulation and that the decreased metabolic rate at $21^{\circ} \mathrm{C}$ is unlikely to be caused by resistance of adipose tissue to sympathetic stimulation.

To examine further the physiological response of adipose tissue to $\beta_{3}$-adrenergic stimulation in $\mathrm{m}-/+$ mice, we measured the rise in serum glycerol and FFA after a maximal dose of CL316243 to fasted mice. Glycerol and FFA concentrations were similar in $\mathrm{m}-/+$ mice and their wild-type littermates at baseline and at $15 \mathrm{~min}$ utes and 2 hours after CL316243 administration (Figure $4 \mathrm{f}$ and data not shown), consistent with a normal lipolytic response to maximal $\beta_{3}$-adrenergic stimulation. The responses of serum insulin and glucose levels to CL316243 were also normal in $\mathrm{m}-/+$ mice, with serum insulin levels increasing markedly and serum $\mathrm{m}-/+$ mice result from increased and decreased sympathetic input to adipose tissue, respectively. To look for differences in sympathetic activity in $+/ \mathrm{p}-$ and $\mathrm{m}-/+$ mice, we collected urine for 72 hours and measured urinary norepinephrine (NE), epinephrine (EPI), and dihydroxyphenylalanine (DOPA), as well as dihydroxyphenylglycol (DHPG) and dihydroxyphenylacetic acid (DOPAC), the deaminated metabolites of NE and dopamine, respectively (Table 3 ). To correct for differences in collection and lean body mass, all were normalized to urine creatinine. These measurements provide a measure of total sympathetic activity and do not assess the sympathetic input to specific tissues, such as adipose tissue. NE, which primarily reflects neural sympathetic activity (35), was increased by approximately $20 \%$ in $+/ p-$ mice and decreased by approximately $20 \%$ in $\mathrm{m}-/+$ mice, which correlates well with the reciprocal changes in metabolic rate observed in these 2 groups of mice. The differences in urinary NE levels between $+/ \mathrm{p}-$ and $\mathrm{m}-/+$ mice were statistically significant $(P<0.01$; Table 3$)$. DHPG is formed primarily by presynaptic reuptake and deamination of NE by monoamine oxidase. Consistent with the results for NE, there is a tendency for DHPG lev-

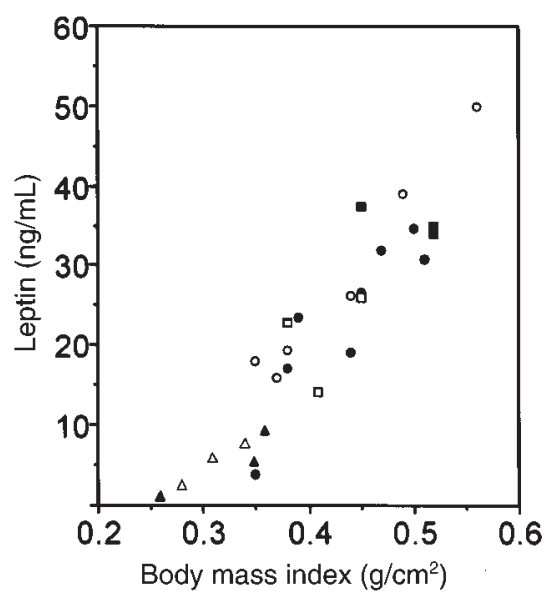

\section{Figure 3}

Correlation between leptin and $\mathrm{BMI}$ in $\mathrm{m}-/+,+/ \mathrm{p}^{-}$, and wild-type mice. Serum leptin levels of individual adult wild-type (filled circles, open circles), +/p- (filled triangles, open triangles), and m-/+ (filled squares, open squares) mice are plotted as a function of their BMI. Male (filled circle, filled triangle, filled square) and female (open circle, open triangle, open square) mice followed similar curves. 
a
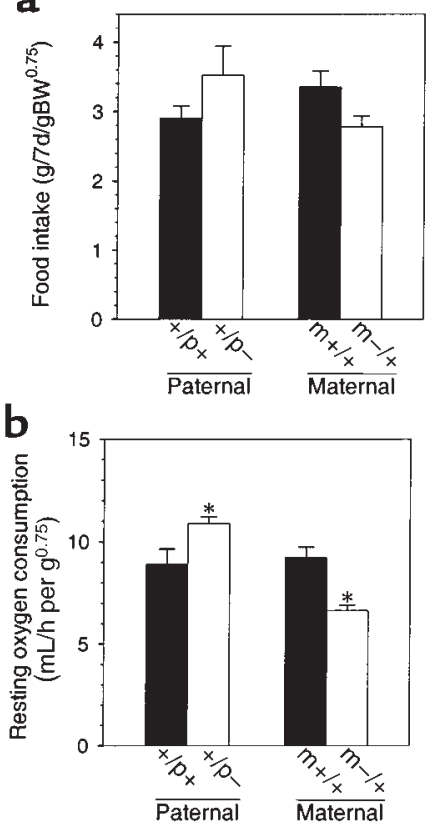

c

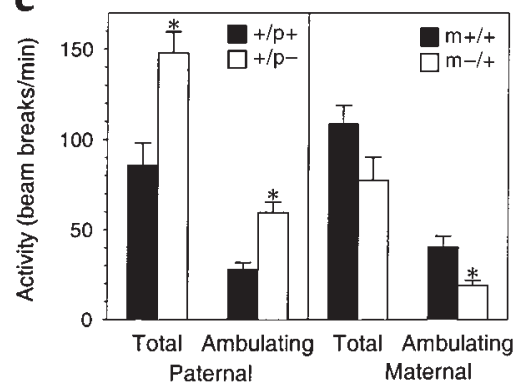

d

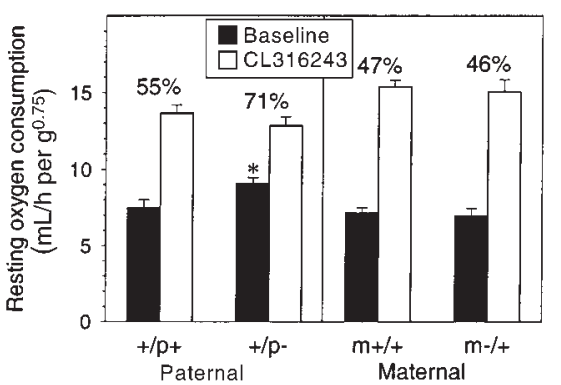

$\mathbf{e}$

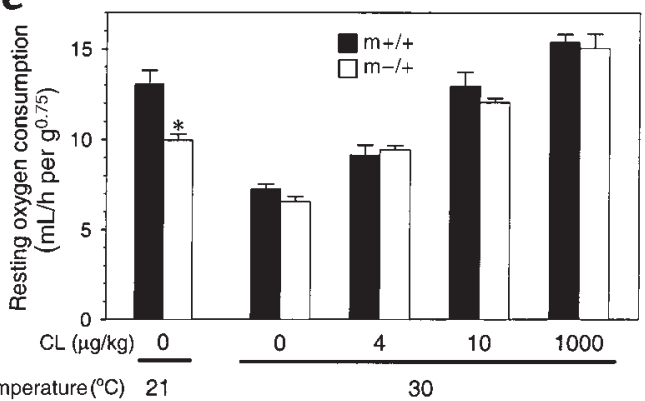

$f$

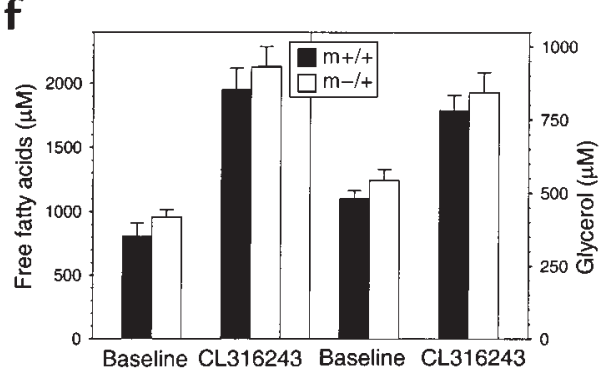

Figure 4

Food intake and metabolic studies in $\mathrm{m}-/+$ and +/p- mice. (a) Food intake in 6- to 8-week-old male mice over a 7-day period normalized to (body weight) ${ }^{0.75}$ (60-62). Data for mutant mice are shown as open bars, and data for wild-type mice are shown as filled bars ( $n=6-8$ mice per group). (b) Resting oxygen consumption at $21^{\circ} \mathrm{C}$ in 7-month-old female mice measured over a 24 -hour period $(n=$ 5 pairs of mice in each group). (c) Total and ambulating activity measured over 24 hours in mice studied in b. (d) Resting oxygen consumption at $30^{\circ} \mathrm{C}$ of 6- to 8-week-old female mice before (filled bars) and after (open bars) administration of a maximal dose of CL316243 $(1,000 \mu \mathrm{g} / \mathrm{kg}$ intraperitoneally; $n=5$ mice per group). For each group, the metabolic rate in the absence of agonist expressed as a percent of maximal metabolic rate is shown above. (e) Resting oxygen consumption in 6- to 8-week-old female $\mathrm{m}-/+$ (open bars) and wild-type littermates (filled bars; $n=5$ pairs) at $21^{\circ} \mathrm{C}$ is shown at the left. To the right is resting oxygen consumption in similar mice at $30^{\circ} \mathrm{C}$ treated with the indicated intraperitoneal doses of CL316243 ( $n=4-10$ pairs of mice at each dose). (f) Serum FFAs (left panel) and glycerol (right panel) in 6-hour fasted 13-week-old male m-/+ mice (open bars) and wild-type littermates (filled bars) before and 15 minutes after administration of a maximal dose of CL316243 $(1,000 \mu \mathrm{g} / \mathrm{kg}$ intraperitoneally; $n=5$ mice per group). In all panels, data are expressed as the mean \pm SEM, and an asterisk indicates $P<0.05$ versus wild-type littermates by $t$ test.

els to be increased in $+/ \mathrm{p}-$ mice and decreased in $\mathrm{m}-/+$, although these results are more difficult to interpret, as there is significant disparity between the 2 wild-type groups. The results for NE and DHPG suggest increased overall neural sympathetic activity in $+/ \mathrm{p}$ - and decreased activity in $\mathrm{m}-/+$ mice. In contrast, EPI, which primarily reflects adrenomedullary activity (35), is similar in mutant and wild-type mice. DOPA, a precursor for NE and EPI, is the product of tyrosine hydroxylase, the ratelimiting enzyme in catecholamine biosynthesis. Urinary DOPA is elevated in both $\mathrm{m}-/+$ and $+/ \mathrm{p}-$ mice, suggesting that the differences in sympathetic activity (reflected by NE) are not due to changes in catecholamine biosynthesis. DOPAC, a neuronal metabolite of DA, is similar in all groups. In summary, the results of urinary catecholamines suggest that adrenomedullary activity is unaffected, whereas neural sympathetic activity is increased in $+/ \mathrm{p}-$ mice and decreased in $\mathrm{m}-/+$ mice. These changes in sympathetic activity might lead to the increased and decreased locomotor activity observed in $+/ \mathrm{p}-$ and $\mathrm{m}-/+$ mice, respectively.

\section{Discussion}

In this article, we show that a heterozygous mutation in Gnas leads to obesity when present within the maternal allele and to leanness when present within 
the paternal allele. In terms of energy metabolism, $\mathrm{m}-/+$ and $+/ \mathrm{p}-$ mice are distinct mouse models with opposite effects on both activity levels and resting energy expenditure, which are reduced in $\mathrm{m}-/+$ mice and elevated in $+/ \mathrm{p}-$ mice.

BAT generates heat upon stimulation by local sympathetic nerves. Chronic stimulation of BAT increases its capacity for thermogenesis by increasing UCP1 expression, the number of mitochondria per cell, and cell number $(26,27)$. BAT is important for 2 functions: maintenance of body temperature by nonshivering thermogenesis, and maintenance of energy balance (and therefore normal weight) by diet-induced thermogenesis, in which excess caloric intake is dissipated as heat $(27,36)$. The role of BAT in the maintenance of energy balance is underscored by the fact that mice with partial ablation of BAT (the UCP1DTA model) develop obesity (37). Understimulation of BAT in $\mathrm{m}-/+$ mice is suggested by its histological appearance and decreased UCP1 expression. Similar changes in BAT are observed in mice lacking leptin (38), UCP1 (39), or the catecholamines NE and EPI (40). Although partial ablation of BAT leads to hyperphagia $(37,41)$, suggesting that BAT might have a role in regulating food intake, the obesity in $\mathrm{m}-/+$ mice is not associated with hyperphagia.

RMR in $\mathrm{m}-/+$ mice is normal at thermoneutrality $\left(30^{\circ} \mathrm{C}\right)$, a condition associated with minimal sympathetic stimulation of BAT (34). However, at a temperature below thermoneutrality $\left(21^{\circ} \mathrm{C}\right), \mathrm{m}-/+$ mice did not raise their energy expenditure to the same extent as wild-type mice. This is reminiscent of UCP1-DTA mice, which develop obesity at room temperature but not at thermoneutrality (42). It seemed likely that the reduced RMR at $21^{\circ} \mathrm{C}$ in $\mathrm{m}-/+$ mice is caused by decreased responsiveness of adipose tissue to sympathetic stimulation due to a lower abundance of $G_{s} \alpha$. However, the physiological response of adipose tissue to $\beta_{3}$-adrenergic stimulation appears to be normal in these mice, suggesting that either $G_{s} \alpha$ is not rate limiting for signal transduction or that the response requires small changes in intracellular cAMP, as is the case for other cAMP-dependent cellular responses (43-46). Although our studies do not rule out the possibility that adipose tissue in $\mathrm{m}-/+$ mice is resistant to $\beta_{1}$ - or $\beta_{2}$-adrenergic stimulation, we believe that this is unlikely. In skeletal muscle, the lack of imprinting of $\mathrm{G}_{\mathrm{s}} \alpha$ in skeletal muscle (leading to similar $\mathrm{G}_{\mathrm{s}} \alpha$ expression levels) and normal UCP3 expression in $\mathrm{m}-/+$ and $+/ \mathrm{p}-$ mice suggest that the observed differences in RMR are not due to differences in the metabolic responsiveness of skeletal muscle to sympathetic stimulation. However, the observed changes in locomotor activity in $\mathrm{m}-/+$ and $+/ \mathrm{p}-$ mice should lead to even greater changes in total energy expenditure. These results and the decreased urinary NE excretion suggest that decreased RMR in $\mathrm{m}-/+$ mice at $21^{\circ} \mathrm{C}$ is due to decreased sympathetic input. However, urinary catecholamines are an integrated measure of sympathetic activity throughout the organism and may not reflect the level of sympathetic activity within specific tissues important for energy metabolism. Definitive assessment of tissue-specific sympathetic activity will require direct measurement of catecholamine levels and turnover rates within specific tissues.

Like $\mathrm{m}-/+$ mice, humans with mutations within the maternal allele of GNAS1 (PHP Ia) develop obesity (3). The physiological mechanisms causing obesity in these patients have not been defined. $\beta$-adrenergic stimulation of adenylyl cyclase is decreased in WAT plasma membranes from patients with PHP Ia, and patients with PHP Ia have decreased serum concentrations of FFAs (47). Thus, it was suggested that the obesity in PHP Ia is due to resistance of adipose tissue to sympathetic stimulation. Alternatively, our results in $\mathrm{m}-/+$ mice suggest that decreased lipolytic activity in adipose tissue of patients with PHP Ia could result from decreased sympathetic stimulation. Sympathetic activity in patients with PHP Ia needs to be directly assessed.

In contrast to $\mathrm{m}-/+$ mice, $+/ \mathrm{p}-$ mice have the reverse phenotype with markedly decreased lipid stores in WAT and increased RMR and activity levels. In 2 transgenic models, overactivity of the cAMP-generating system in adipose tissue leads to increased metabolic activation and decreased lipid stores $(48,49)$. Similarly, adipose tissue in $+/ \mathrm{p}$ - mice appears overstimulated based on the histological appearance of the BAT and WAT and increased UCP1 expression in BAT. $\mathrm{G}_{s} \alpha$ expression in adipose tissue is normal in these mice. Thus, the sensitivity of adipose tissue to sympathetic stimulation is unlikely to be affected. Our data are most consistent with increased sympathetic activity in $+/ \mathrm{p}-$ mice. The $+/ \mathrm{p}$ - mouse model does not mimic the analogous human disease, as patients with PPHP tend to have obesity rather than decreased fat mass. The disparate findings between $+/ \mathrm{p}$ - mice and patients with PPHP might be the result of species-specific differences in the role of BAT in energy balance, in the importance of specific Gnas gene products, and/or in social and environmental factors.

We have shown that a single genetic defect within the maternal or paternal Gnas allele leads to opposite effects on energy metabolism. If the relevant underlying defect is dysregulation of sympathetic pathways in the central nervous system, then opposite effects on sympathetic activation might be caused by disruption

\section{Table 3}

Urinary catecholamines and their metabolites ${ }^{\mathrm{A}}$

$\begin{array}{lcccc} & +/ \mathrm{p}^{+} & +/ \mathrm{p}^{-} & \mathrm{m}+/+ & \mathrm{m}-/+ \\ \text { NE } & 5,200 \pm 600 & 6,200 \pm 600 & 5,100 \pm 700 & 4,000 \pm 200^{\mathrm{B}} \\ \text { EPI } & 480 \pm 60 & 490 \pm 140 & 320 \pm 30 & 290 \pm 40 \\ \text { DHPG } & 480 \pm 110 & 1,200 \pm 200^{C} & 1,100 \pm 300 & 840 \pm 220 \\ \text { DOPA } & 780 \pm 330 & 1,400 \pm 800 & 780 \pm 510 & 1,200 \pm 600 \\ \text { DOPAC } & 5,400 \pm 500 & 7,600 \pm 2400 & 6,400 \pm 700 & 5,700 \pm 1600\end{array}$

AMeasurements in 3- to 4-month-old male $+/ \mathrm{p}-$ and $\mathrm{m}-/+$ mice and paired wild-type littermates ( 5 pairs of each) expressed as $\mathrm{pmol} / \mathrm{mg}$ creatinine (mean \pm SEM). ${ }^{B} P<0.01$ versus $+/ p$ - mice. ${ }^{C} P<0.05$ versus-type littermates. 
of maternal- and paternal-specific Gnas gene products in $\mathrm{m}-/+$ and $+/ \mathrm{p}-$ mice, respectively. $\mathrm{G}_{\mathrm{s}} \alpha$ deficiency in specific regions of the central nervous system due to region-specific imprinting might lead to decreased sympathetic activity in $\mathrm{m}-/+$ mice. Several G protein-coupled receptors (e.g., melanocortin 4 [ref. 50], melanin concentrating hormone [refs. 51 and 52], and serotonin 2c [ref. 53] receptors) have already been implicated in the regulation of energy homeostasis.

Disruption of alternative Gnas products could also play a role in dysregulation of energy metabolism. NESP55 is a maternal-specific Gnas gene product expressed primarily in the adrenal medulla and brain $(16,17)$. However, NESP55 probably does not play a role in the $\mathrm{m}-/+$ phenotype, as the exon 2 insertion does not disrupt the NESP55 coding region, and preliminary results suggest that adrenal expression of NESP55 mRNA is intact in $\mathrm{m}-/+$ mice (S. Yu and L.S. Weinstein, unpublished data). Moreover, obesity develops in patients with PHP Ia in whom GNAS1 missense mutations should not affect NESP55 expression (25). It is also possible that the $+/ \mathrm{p}$ - phenotype results from loss of expression of the paternal-specific Gnas gene product XL $\alpha$ s, which is primarily expressed in the central nervous system (13). Specific knockouts will help define the role of these alternative Gnas products in the maternal and paternal GsKO phenotypes.

It has been proposed that genomic imprinting is the result of conflicting parental goals, whereby it is in the father's interest for his offspring to gain the most resources, whereas it is in the mother's interest to conserve resources so all of her offspring can survive (54). This model predicts that genes contributed by the father would promote growth, whereas those contributed by the mother would inhibit growth. This has been shown for some imprinted genes, such as Igf2 and $\operatorname{Igf} 2 r(55-57)$, but has not been found consistently in all imprinted genes $(58,59)$. For most of these genes, the major effect is on prenatal growth. GsKO mice confirm and extend this model to postnatal growth, as disruption of the paternal allele leads to decreased prenatal growth, failure to suckle at birth, and markedly reduced accumulation of energy stores postnatally, whereas disruption of the maternal allele leads to opposite effects.

\section{Acknowledgments}

We thank B. Marcus-Samuels, C. Holmes, A. Remaley, and T. Bosworth for technical assistance, and V. Susulic at Wyeth-Ayerst for providing CL316243. A.F. Parlow is supported by NIH contract DK-9-2246.

1. Spiegel, A.M., Shenker, A., and Weinstein, L.S. 1992. Receptor-effector coupling by $G$ proteins: implications for normal and abnormal signal transduction. Endocr. Rev. 13:536-565.

2. Gejman, P.V., et al. 1991. Genetic mapping of the Gs- $\alpha$ subunit gene (GNAS1) to the distal long arm of chromosome 20 using a polymorphism detected by denaturing gradient gel electrophoresis. Genomics. 9:782-783.

3. Weinstein, L.S. 1998. Albright hereditary osteodystrophy, pseudohypoparathyroidism and $\mathrm{G}_{\mathrm{s}}$ deficiency. In $\mathrm{G}$ proteins, receptors, and disease. A.M. Spiegel, editor. Humana Press. Totowa, NJ. 23-56.

4. Davies, S.J., and Hughes, H.E. 1993. Imprinting in Albright's heredi- tary osteodystrophy. J. Med. Genet. 30:101-103.

5. Bartolomei, M.S., and Tilghman, S.M. 1997. Genomic imprinting in mammals. Annu. Rev. Genet. 31:493-525.

6. Tilghman, S.M. 1999. The sins of the fathers and mothers: genomic imprinting in mammalian development. Cell. 96:185-193.

7. Constancia, M., Pickard, B., Kelsey, G., and Reik, W. 1998. Imprinting mechanisms. Genome Res. 8:881-900.

8. Yu, S., et al. 1998. Variable and tissue-specific hormone resistance in heterotrimeric $\mathrm{G}_{\mathrm{s}}$ protein $\alpha$-subunit $\left(\mathrm{G}_{\mathrm{s}} \alpha\right)$ knockout mice is due to tissue-specific imprinting of the $\mathrm{G}_{\mathrm{s}} \alpha$ gene. Proc. Natl. Acad. Sci. USA. 95:8715-8720.

9. Campbell, R., Gosden, C.M., and Bonthron, D.T. 1994. Parental origin of transcription from the human GNAS1 gene. J. Med. Genet. 31:607-614.

10. Hayward, B.E., et al. 1998. The human GNAS1 gene is imprinted and encodes distinct paternally and biallelically expressed $G$ proteins. Proc. Natl. Acad. Sci. USA. 95:10038-10043.

11. Hayward, B.E., Moran, V., Strain, L., and Bonthron, D.T. 1998. Bidirectional imprinting of a single gene: GNAS1 encodes maternally, paternally, and biallelically derived proteins. Proc. Natl. Acad. Sci. USA 95:15475-15480

12. Peters, J., et al. 1999. A cluster of oppositely imprinted transcripts at the Gnas locus in the distal imprinting region of mouse chromosome 2. Proc. Natl. Acad. Sci. USA. 96:3830-3835.

13. Kehlenbach, R.H., Matthey, J., and Huttner, W.B. 1994. XLos is a new type of G protein. Nature. 372:804-809.

14. Ischia, R., et al. 1997. Molecular cloning and characterization of NESP55, a novel chromogranin-like precursor of a peptide with 5$\mathrm{HT}_{1 \mathrm{~B}}$ receptor antagonist activity. J. Biol. Chem. 272:11657-11662.

15. Bauer, R., et al. 1999. The new chromogranin-like protein NESP55 is preferentially localized in adrenaline-synthesizing cells of the bovine and rat adrenal medulla. Neurosci. Lett. 263:13-16.

16. Bauer, R., Ischia, R., Marksteiner, J., Kapeller, I., and Fischer-Colbrie, R. 1999. Localization of neuroendocrine secretory protein 55 messenger RNA in the rat brain. Neuroscience. 91:685-694.

17. Lovisetti-Scamiform, P., Fischer-Colbrie, R., Leitner, B., Scherzer, G., and Winkler, H. 1999. Relative amounts and molecular forms of NESP55 in various bovine tissues. Brain Res. 829:99-106.

18. Cattanach, B.M., and Kirk, M. 1985. Differential activity of maternally and paternally derived chromosome regions in mice. Nature. 315:496-498

19. Cattanach, B.M., and Beechey, C.V. 1990. Autosomal and X-chromosome imprinting. Development. (Suppl.):63-72.

20. Bloom, J.D., et al. 1992. Disodium (R,R)-5 [2-[[2-(3-chlorophenyl)-2hydroxyethyl]-amino]propyl]-1,3- benzodioxole-2,2-dicarboxylate (CL 316,243). A potential beta-adrenergic agonist virtually specific for beta 3 receptors. A promising antidiabetic and antiobesity agent. J. Med. Chem. 35:3081-3084.

21. Moyer, T.P., Jiang, N.-S., Tyce, G.M., and Sheps, S.G. 1979. Analysis of urinary catecholamines by liquid chromatography with amperometric detection: methodology and clinical interpretation of results. Clin. Chem. 25:256-263.

22. Gong, D.-W., He, Y., Karas, M., and Reitman, M. 1997. Uncoupling protein-3 is a mediator of thermogenesis regulated by thyroid hormone, $\beta 3$-adrenergic agonists, and leptin. J. Biol. Chem. 272:24129-24132.

23. Gong, D.-W., He, Y., and Reitman, M.L. 1999. Genomic organization and regulation by dietary fat of the uncoupling 3 and 2 genes. Biochem. Biophys. Res. Commun. 256:27-32.

24. Sullivan, K.A., et al. 1986. Inhibitory and stimulatory G protein of adenylate cyclase: cDNA and amino acid sequences of the alpha chains. Proc. Natl. Acad. Sci. USA. 83:6687-6691.

25. Warner, D.R., Gejman, P.V., Collins, R.M., and Weinstein, L.S. 1997. A novel mutation adjacent to the switch III domain of $G_{s \alpha}$ in a patient with pseudohypoparathyroidism. Mol. Endocrinol. 11:1718-1727.

26. Nicholls, D.G., and Locke, R.M. 1984. Thermogenic mechanisms in brown fat. Physiol. Rev. 64:1-64.

27. Himms-Hagen, J., and Ricquier, D. 1998. Brown adipose tissue. In Handbook of obesity. G.A. Bray, C. Bouchard, and W.P.T. James, editors. Marcel Dekker Inc. New York, NY. 415-441.

28. Silva, J.E., and Rabelo, R. 1997. Regulation of the uncoupling protein gene expression. Eur. J. Endocrinol. 136:251-264.

29. Friedman, J.M., and Halaas, J.L. 1998. Leptin and the regulation of body weight in mammals. Nature. 395:763-770.

30. Considine, R.V., et al. 1996. Serum immunoreactive-leptin concentrations in normal-weight and obese humans. N. Engl. J. Med. 334:292-295.

31. Giacobino, J.P. 1996. Role of the beta 3-adrenoreceptor in the control of leptin expression. Horm. Metab. Res. 28:633-637.

32. Herrington, L.P. 1940 . The heat regulation of small laboratory animals at various environmental temperatures. Am. J. Physiol. 129:123-139. 
33. Pennycuik, P.R. 1967. A comparison of the effects of a variety of factors on the metabolic rate of the mouse. Aust. J. Exp. Biol. Med. Sci. 45:331-346.

34. Zaror-Behrens, G., and Himms-Hagen, J. 1983. Cold-stimulated sympathetic activity in brown adipose tissue of obese $(o b / o b)$ mice. Am. $J$ Physiol. 244:E361-E366.

35. Goldstein, D.S. 1995. Stress, catecholamines, and cardiovascular disease. Oxford University Press. New York, NY. 539 pp.

36. Rothwell, N.J., and Stock, M.J. 1979. A role for brown adipose tissue in diet-induced thermogenesis. Nature. 281:31-35.

37. Lowell, B.B., et al. 1993. Development of obesity in transgenic mice after genetic ablation of brown adipose tissue. Nature. 366:740-742.

38. Trayhurn, P. 1986. Brown adipose tissue and energy metabolism. In Brown adipose tissue. P. Trayhurn and D.G. Nicholls, editors. Edward Arnold. London, United Kingdom. 299-338.

39. Enerback, S., et al. 1997. Mice lacking mitochondrial uncoupling protein are cold-sensitive but not obese. Nature. 387:90-94.

40. Thomas, S.A., and Palmiter, R.D. 1997. Thermoregulatory and metabolic phenotypes of mice lacking noradrenaline and adrenaline. Nature. 387:94-97.

41. Melnyk, A., and Himms-Hagen, J. 1998. Temperature-dependent feeding: lack of role for leptin and defect in brown adipose tissueablated obese mice. Am. J. Physiol. 274:R1131-R1135.

42. Melnyk, A., Harper, M.-E., and Himms-Hagen, J. 1997. Raising at thermoneutrality prevents obesity and hyperphagia in BAT-ablated transgenic mice. Am. J. Physiol. 272:R1088-R1093.

43. Levine, M.A., et al. 1983. Resistance to multiple hormones in patients with pseudohypoparathyroidism. Association with deficient activity of guanine nucleotide regulatory protein. Am. J. Med. 74:545-556.

44. Brickman, A.S., Carlson, H.E., and Levin, S.R. 1986. Responses to glucagon infusion in pseudohypoparathyroidism. J. Clin. Endocrinol. Metab. 63:1354-1360.

45. Carlson, H.E., and Brickman, A.S. 1983. Blunted plasma cyclic adenosine monophosphate response to isoproterenol in pseudohypoparathyroidism. J. Clin. Endocrinol. Metab. 56:1323-1326.

46. Chou, C., DiGiovanni, S.R., Luther, A., Lolait, S.J., and Knepper, M.A. 1995. Oxytocin as an antidiuretic hormone II. Role of $V_{2}$ vasopressin receptor. Am. J. Physiol. 269:F78-F85.

47. Kaartinen, J.M., Käär, M.-L., and Ohisalo, J.J. 1994. Defective stimulation of adipocyte adenylate cyclase, blunted lipolysis, and obesity in pseudohypoparathyroidism 1a. Pediatr. Res. 35:594-597.

48. Cummings, D.E., et al. 1996. Genetically lean mice result from tar geted disruption of the RII $\beta$ subunit of protein kinase A. Nature. 382:622-626

49. Soloveva, V., Graves, R.A., Rasenick, M.M., Spiegelman, B.M., and Ross, S.R. 1997. Transgenic mice overexpressing the $\beta 1$-adrenergic receptor in adipose tissue are resistant to obesity. Mol. Endocrinol. 11:27-38.

50. Huszar, D., et al. 1997. Targeted disruption of the melanocortin-4 receptor results in obesity in mice. Cell. 88:131-141.

51. Chambers, J., et al. 1999. Melanin-concentrating hormone is the cognate ligand for the orphan G protein-coupled receptor SLC-1. Nature. 400:261-265.

52. Saito, Y., et al. 1999. Molecular characterization of the melanin-concentrating-hormone receptor. Nature. 400:265-269.

53. Tecott, L.H., et al. 1995. Eating disorder and epilepsy in mice lacking 5-HT2c serotonin receptors. Nature. 374:542-546.

54. Moore, T., and Haig, D. 1991. Genomic imprinting in mammalian development: a parental tug-of-war. Trends Genet. 7:45-49.

55. DeChiara, T.M., Robertson, E.J., and Efstradiadis, A. 1991. Parental imprinting of the mouse insulin-like growth factor II gene. Cell. 54:849-859.

56. Lau, M.M., et al. 1994. Loss of the imprinted IGF2/cation-dependent mannose 6-phosphate receptor results in fetal overgrowth and perinatal lethality. Genes Dev. 8:2953-2963.

57. Ludwig, T., et al. 1996. Mouse mutants lacking the type 2 IGF receptor (IGF2) are rescued from perinatal lethality in Igf2 and Igf1r null backgrounds. Dev. Biol. 177:517-535.

58. Hurst, L.D., and McVean, G.T. 1997. Growth effects of uniparental disomies and the conflict theory of genomic imprinting. Trends Genet. 13:436-443.

59. Isawa, Y. 1998. The conflict theory of genomic imprinting: how much can be explained? Curr. Top. Dev. Biol. 40:255-293.

60. Kleiber, M. 1961. In The fire of life: an introduction to animal energetics. John Wiley \& Sons. New York, NY. 454pp.

61. West, G.B., Brown, J.H., and Enquist, B.J. 1999. The fourth dimension of life: fractal geometry and allosteric scaling of organisms. Science. 284:1677-1679.

62. Banavar, J.R., Maritan, A., and Rinaldo, A. 1999. Size and form in efficient transportation networks. Nature. 399:130-132. 